\title{
Comparison of Shear Bond Strength Orthodontic Brackets Bonded to Zirconia and Lithium Disilicate Crowns
}

\section{Usporedba posmične čvrstoće veze ortodontskih bravica lijepljenih na cirkonijeve i litijeve disilikatne krunice}

\author{
${ }^{1}$ Department of Orthodontics and Pedodontics, Medical Faculty - School of Dentistry, University of Pristina, Kosovo. \\ Zavod za ortodonciju i pedodonciju Medicinskog fakulteta Sveučilišta u Prištini, Kosovo \\ 2 School of Dental Medicine - Ph.D. studies, University of Zagreb, Croatia. \\ Stomatološki fakultet Sveučilišta u Zagrebu - studentica doktorskog studija \\ ${ }^{3}$ School of Dental Medicine, University College AAB, Pristina, Kosovo. \\ Stomatološki fakultet Sveučilišta u Prištini, Kosovo \\ 4 Department for Materials, Faculty of Mechanical Engineering and Naval Architecture, University of Zagreb, Croatia. \\ Zavod za materijale Strojarskog fakulteta Sveučilišta u Zagrebu, Hrvatska \\ ${ }^{5}$ Department of Orthodontics, School of Dental Medicine, University of Zagreb, Croatia. \\ Zavod za ortodonciju Stomatološkog fakulteta Sveučilišta u Zagrebu, Hrvatska
}

\section{Abstract}

Aim of this study was to analyze Shear Bond Strength (SBS) and Adhesive Remnant Index (ARI) of ceramic and metallic orthodontic brackets bonded to zirconia or lithium-disilicate ceramics used for prosthetic restorations, conditioned with hydrofluoric acid (HFA) or phosphoric acid (PhA), as well as to determine the Porcelain Fracture Index (PFI), in order to examine the condition of the ceramic surface after debonding. Material and methods: The research was conducted on 96 prepared all-ceramic samples divided into 8 groups combined from the type of ceramic material, orthodontic brackets, and surface conditioning. SBS was tested with Universal Testing Machine, and the samples were analyzed using a Scanning Electron Microscope, to determine ARI and PFI. Statistical data were processed using ANOVA, with the level of significance $\alpha=0.05$. Results: Lithium-disilicate showed better bond strength in almost all groups. However, no significant difference between the groups was noticed and none of the factors had a significant influence on the mean values of SBS ( $p>0.05)$. Nevertheless, ARI significantly depended on the type of bracket $(p=0.005)$, and PFI significantly depended on the type of etchant $(p=0.029)$. Conclusion: The use of HFA for surface etching of zirconia and lithium-disilicate, does not cause a significant increase in the SBS values as compared to etching with PhA and silane application. Furthermore, HFA can weaken the surface structure of the ceramic, and considering its toxicity, might not be the best suitable conditioner prior to orthodontic bonding to lithium disilicate, and in particular to zirconia, also taking into account its crystalline structure.
Received: November 15, 2018

Accepted: February 1, 2019

Address for correspondence

Sandra Anić-Milošević

University of Zagreb

School of Dental Medicine

Gunduliceva 5, 10000 Zagreb, Croatia

tel:+38514802173

sanic@sfzg.hr

Key words

Orthodontic Brackets; Shear Bond Strength; Crowns; Adhesive Remnant Index (ARI); Porcelain Fracture Index (PFI); Zirconia; Lithium Compounds

\section{Introduction}

Metal-free materials used as dental restorations have been in the spotlight of recent research, following the introduction of innovative all-ceramic materials (1). Also, the rising demand for more facial esthetics has increased the request for adult orthodontics (2). However, orthodontic brackets bond poorly to ceramic surfaces, unless the surface characteristics of the ceramic are altered through certain approaches before bonding (3).

Earlier studies reported that bond strength of brackets to various restorations can be connected to many factors, such as restoration material and its surface conditioning, the material and the design of the bracket, the properties of the bond system, as well as the light-curing device. Hereupon, the combination of these and other factors may be very important for successful treatment (4-6).
Uvod

Uvođenjem inovativnih potpuno keramičkih materijala, nemetalni materijali koji se koriste $\mathrm{u}$ dentalnim restauracijama već dugo su predmet najnovijih istraživanja (1). I sve veći zahtjevi za estetikom lica povećali su potrebu za time, pa se sve veći broj odraslih pacijenata odlučuje za ortodontsku terapiju (2). Inače, ortodontske bravice dosta se loše lijepe na keramičke površine, osim ako njihova površinska karakteristika nije promijenjena određenim postupcima prije lijepljenja (3).

Dosadašnja istraživanja pokazala su da je čvrstoća vezivanja bravica na različitim restauracijama povezana s mnogobrojnim čimbenicima, kao što su vrsta restaurativnog materijala i način hrapavljenja površine, materijal i oblik bravice, svojstva ljepila i svjetlosno polimerizirajuće svjetiljke. Kombinacija tih i drugih čimbenika može biti vrlo važna za uspješnost terapije $(4-6)$. 
In recent past, we witnessed fast high-tech evolution of various all-ceramic dental restorations (6,7). Partially stabilized zirconia is a very common choice in dentistry, because of its indisputable mechanical properties, chemical inertness and excellent optical properties (7). Another hot-spot all-ceramic that includes excellent esthetics with proper strength is lithium disilicate (7-9).

The type of ceramic used as restoration can be a decisive factor for the binding of orthodontic attachments and for the method of altering their surface before bonding. In the past, various surface treatment methods of the ceramic surface were introduced, such as diamond burs, sandblasting, hydrofluoric acid (HFA), phosphoric acid (PhA), laser etching, etc., exposing their advantages and disadvantages (10-15). Mechanical removal of the glazed surface of the ceramic with diamond burs as well as sandblasting aluminum-oxide particles with high pressure can enhance bond strength, but also can reduce ceramic integrity, which could lead to cracks and larger damages during debonding (16). HFA etching creates a porous surface by removing the glassy matrix (17) and has been shown to result in acceptable bond-strength values in porcelain $(11,14,15)$, but it is less successful in more crystalline rich ceramics. Also, the danger of acid burns is very high, which can result in deep tissue necrosis (18). Conditioning with some lasers has also been investigated, also with not so satisfactory results (19-21). Phosphoric acid (37.0\%) cannot erode superficial layers of silicate ceramic $(10,11,13)$, but it is able to neutralize the alkalinity of the absorbed water present on ceramic restorations in the mouth and thereby making better chemical conditions for the subsequently applied silane (22). It is also not toxic or corrosive and in combination with silane achieves satisfactory bond strength $(13,22)$. The use of silane increases the adhesion of the composite resin bond to ceramics $(11,13,23)$, by creating a chemical link between the hydroxyl $(\mathrm{OH})$ of the silica of the ceramic with the resinous matrix of the composite $(6,17,24)$. However, with the increase of the crystalline phase in the content of the ceramic, this chemical reaction becomes less efficient, because of lower levels of silica (17).

When bonding onto ceramic surfaces, the material type consisting orthodontic brackets and their base surface design should also be considered. Oftentimes, adhesion of ceramic brackets is higher compared to metallic brackets, because of the better light transmittance allowing stronger photo-polymerization. This is also due to a different failure mode because of the flexibility of the metal base $(4,6,13,24,25)$.

Currently, there is no consensus regarding the most efficient ceramic surface conditioning method for producing optimal bond strength of orthodontic attachments to various ceramic surfaces. The purpose of this research was to conduct a comparative analysis of Shear Bond Strength (SBS) and of Adhesive Remnant Index (ARI), or ceramic and metallic brackets bonded to zirconia and lithium disilicate ceramic surfaces used for prosthetic restorations, conditioned with $5 \% \mathrm{HFA}$ or $37 \% \mathrm{PhA}$, and silane. Also, the objective of this research was to investigate the Porcelain Fracture Index (PFI), in order to examine the condition of the ceramic surface after debonding.
Posljednjih godina svjedoci smo tehnološke evolucije različitih potpuno keramičkih zubnih restauracija $(6,7)$. Djelomično stabilizirani cirkonij vrlo je uobičajen u dentalnoj medicini zbog svojih nespornih mehaničkih obilježja, kemijske inertnosti i izvrsnih optičkih karakteristika (7). Keramika sličnih performansa, s izvrsnom estetikom i odgovarajućom tvrdoćom, jest i litijev disilikat $(7-9)$.

Vrsta keramike kojom se koristimo za restauracije može biti odlučujući čimbenik za vezivanje ortodontskih bravica te za metodu kojom ćemo pripremiti keramičku površinu prije lijepljenja bravica. Prije su prikazani mnogi načini pripreme površine keramike, primjerice, dijamantnim svrdlima, pjeskarenjem, fluorovodičnom kiselinom, fosfornom kiselinom te jetkanjem laserom, sa svim njihovim prednostima i nedostatcima $(10-15)$. Mehaničko uklanjanje keramičke glazure dijamantnim svrdlima i pjeskarenje česticama aluminijeva oksida pod visokim tlakom može poboljšati čvrstoću vezivanja, ali s druge strane smanjuje integritet keramike, što može uzrokovati pucanje ili veća oštećenja pri skidanju bravica (16). Jetkanje fluorovodičnom kiselinom (HFA) stvara poroznu površinu uklanjanjem staklenog matriksa (17) te je utvrđeno da rezultira prihvatljivim vrijednostima čvrstoće vezivanja kod porculana $(11,14,15)$, ali je manje uspješno u slučaju više kristalične keramike. Vrlo je velika i opasnost od opeklina prouzročenih kiselinom, što može rezultirati dubokom nekrozom tkiva. (18). Ispitivana su također jetkanja površine laserom, no rezultati nisu baš zadovoljili (19 - 21). Fosforna kiselina $(37,0 \%)$ ne može erodirati površinski sloj silikatne keramike $(10,11,13)$, ali može neutralizirati alkalnost apsorbirane vode u keramičkim restauracijama u usnoj šupljini, čime ostvaruje kemijske uvjete za uporabu silana (22). Ona nije ni toksična, ni korozivna, a u kombinaciji sa silanom postiže zadovoljavajuću čvrstoću vezivanja (13, 22). Korištenje silana povećava adheziju kompozitne smole za keramiku $(11,13,23)$ stvaranjem kemijske veze između hidroksila $(\mathrm{OH})$ silikatne keramike sa smolastim matriksom kompozita $(6,17,24)$. No povećanjem kristalične faze u sastavu keramike, takva kemijska reakcija postaje manje učinkovita zbog smanjene razine silikata (17).

Pri lijepljenju bravica na keramičke površine također bi trebalo uzeti u obzir vrstu materijala od kojeg su izrađene ortodontske bravice te oblik njezine baze. Često lijepljenje keramičkih bravica na keramiku jače je u odnosu prema metalnim bravicama zbog boljeg propuštanja svjetla, čime je omogućena bolja fotopolimerizacija. Razlog može biti i različita fleksibilnost metalne baze $(4,6,13,24,25)$.

Trenutačno nema konsenzusa o tome koji je način pripreme keramičke površine najbolji za optimalnu čvrstoću vezivanja ortodontskih bravica na različitim keramičkim površinama. Cilj ovog istraživanja bio je obaviti komparativnu analizu posmične čvrstoće vezivanja (SBS) i utvrditi indeks zaostatnog sloja adheziva keramičkih i metalnih ortodontskih bravica lijepljenih na cirkonijevu i litijevu disilikatnu površinu keramičkih krunica koje se koriste za protetičke restauracije koje su prije toga najetkane 5-postotnom fluorovodičnom kiselinom ili 37-postotnom fosfornom kiselinom i silanom. Sljedeći cilj ovoga rada bio je istražiti indeks loma keramike (PFI) kako bi se ispitalo stanje keramičke površine nakon skidanja bravica. 


\section{Material and methods}

\section{Preparation of specimens}

The research was conducted on 96 all-ceramic crowns, of which 48 full contour zirconia (Copran Zr-i Monolith, White Peaks Dental Solutions GmbH\&Co.KG, Wesel, Essen, Germany), and 48 lithium disilicate (IPS EMAX CAD, Ivoclar Vivadent AG Schaan, Lichtenstein). Metallic orthodontic brackets (Mini 2000 Ormco Corp., Glendora, California, USA) and ceramic orthodontic brackets (Glam Forestadent, Bernhard Forster GmbH, Pforzheim, Germany) were equally bonded to these crowns. Two different etching materials were used for conditioning of the surface of ceramic crowns: 5\% HFA (IPS Ceramic Etching Gel, Ivoclar Vivadent AG, Schaan, Lichtenstein) or 37\% PhA (Etching solution, Ormco Corp., Glendora, CA, USA) for 120 $s$, and subsequently silane (Prosil, Dentscare, Joinville, Brasil) was applied. Two-component (primer and adhesive) composite resin-based bonding system (Tranbond XT, 3M/Unitek, Monrovia, CA, USA) was used for bonding the brackets. The brackets were bonded in the middle of the prepared surfaces of the ceramic sample by the same operator. They were pressed firmly, and the excess adhesive was removed from around the bracket base using a dental probe. The adhesive was light-cured for $40 \mathrm{~s}$ (4), using a light-emitting diode (LED; Edition, Ivoclar Vivadent AG, Schaan, Lichtenstein). Prior to testing, the crowns were embedded in a two-component epoxy filling (Epoxy Repair, Bison International, Goes, The Netherlands). Additionally, five days after bonding the brackets, the specimens were thermocycled $\left(5800\right.$ cycles, $5^{\circ} \mathrm{C}$ to $55^{\circ} \mathrm{C}$ in distilled water, with $10 \mathrm{~s}$ dwelling time), in order to simulate the moisture of the oral environment.

\section{Groups}

The sample was divided into 8 groups: 1 . Metallic bracket bonded to zirconia surface etched with PhA; 2. Metallic bracket bonded to zirconia surface etched with HFA; 3. Ceramic bracket bonded to zirconia surface etched with $\mathrm{PhA}$; 4. Ceramic bracket bonded to zirconia surface etched with HFA; 5. Metallic bracket bonded to lithium disilicate surface etched with $\mathrm{PhA} ; 6$. Metallic bracket bonded to lithium disilicate surface etched with HFA; 7. Ceramic bracket bonded to lithium disilicate surface etched with $\mathrm{PhA}$; and 8 . Ceramic bracket bonded to lithium disilicate surface etched with HFA.

\section{SBS testing}

SBS was tested with Universal Testing Machine (Erichsen 0-2000 N, ISO 7500-1:1, AM Erichsen GmbH\&Co.KG, Hemer-Sundwig, Germany), with a load applied parallel to the buccal surface of the crown in a gingival-occlusal direction, using a knife-edged rod moving at fixed rate of $1 \mathrm{~mm} /$ min, until failure occurred. The force required to debond the brackets was recorded in Newton, and the values were calculated to MPa. (Figure 1).

\section{Materijali i metode}

\section{Priprema uzorka}

Istraživanje je provedeno na 96 keramičkih krunica 48 cirkonijevih (Copran Zr-i Monolith, White Peaks Dental Solutions GmbH\&Co.KG, Wesel, Essen, Njemačka) te 48 od litijeva disilikata (IPS EMAX CAD, Ivoclar Vivadent AG Schaan, Lihtenštajn). Metalne ortodontske bravice (Mini 2000 Ormco Corp., Glendora, California, SAD) i keramičke ortodontske bravice (Glam Forestadent, Bernhard Forster GmbH, Pforzheim, Njemačka) lijepljene su na navedene krunice $\mathrm{u}$ istom omjeru. Korištena su dva različita materijala za jetkanje keramičkih krunica - 5-postotna fluorovodična kiselina (IPS Ceramic Etching Gel, Ivoclar Vivadent AG, Schaan, Lihtenštajn) i 37-postotna fosforna kiselina (Etching solution, Ormco Corp., Glendora, CA, SAD) u trajanju od 120 sekunda, nakon čega slijedi primjena silana (Prosil, Dentscare, Joinville, Brazil). Dvokomponentni (primer i adheziv) kompozit na bazi smole (Tranbond XT, 3M/ Unitek, Monrovia, CA, SAD) korišten je za lijepljenje bravica. Isti istraživač lijepio je sve bravice točno na sredinu pripremljene površine keramičkog uzorka. Svaki put je bravica bila jednako utisnuta kako bi se višak adheziva oko nje mogao ukloniti sondom. Adheziv je polimeriziran svjetlom 40 sekunda (4) s pomoću svjetlosno emitirajuće diode (LED; Ledition, Ivoclar Vivadent AG, Schaan, Lihtenštajn). Prije testiranja krunice su bile dodatno uronjene u dvokomponentnu epoksidnu smolu (Epoxy Repair, Bison International, Goes, Nizozemska). Pet dana nakon skidanja bravica, uzorak je termocikliran (5800 ciklusa, od $5^{\circ} \mathrm{C}$ do $55^{\circ} \mathrm{C}$ u destiliranoj vodi 10 sekunda), kako bi se simulirala vlažnost usne šupljine.

\section{Skupine}

Uzorak je podijeljen u osam skupina: 1. metalne bravice lijepljene na cirkonijevu površinu jetkanu fosfornom kiselinom (PhA); 2. metalne bravice lijepljene na cirkonijevu površinu jetkanu fluorovodičnom kiselinom (HFA); 3. keramičke bravice lijepljene na cirkonijevu površinu jetkanu fosfornom kiselinom (PhA); 4. keramičke bravice lijepljene na cirkonijevu površinu jetkanu fluorovodičnom kiselinom (HFA); 5. metalne bravice lijepljene na litijevu disilikatnu površinu jetkanu fosfornom kiselinom (PhA); 6. metalne bravice lijepljene na litijevu disilikatnu površinu jetkanu fluorovodičnom kiselinom (HFA); 7. keramičke bravice lijepljene na litijevu disilikatnu površinu jetkanu fosfornom kiselinom (PhA); 8. keramičke bravice lijepljene na litijevu disilikatnu površinu jetkanu fluorovodičnom kiselinom (HFA).

\section{SBS testiranje}

Posmična čvrstoća veze (SBS) testirana je univerzalnim uređajem za ispitivanje materijala (Erichsen 0-2000 N, ISO 7500-1:1, AM Erichsen GmbH\&Co.KG, Hemer-Sundwig, Njemačka), uz opterećenje primijenjeno paralelno s bukalnom površinom krunice u gingivno-okluzalnom smjeru koristeći se oštricom kidalice s fiksiranom brzinom od $1 \mathrm{~mm} /$ min. do granice pucanja. Sila potrebna za skidanje bravica zabilježena je u njutnima, a vrijednosti su izračunate u jedinicama MP-a. (slika 1.). 


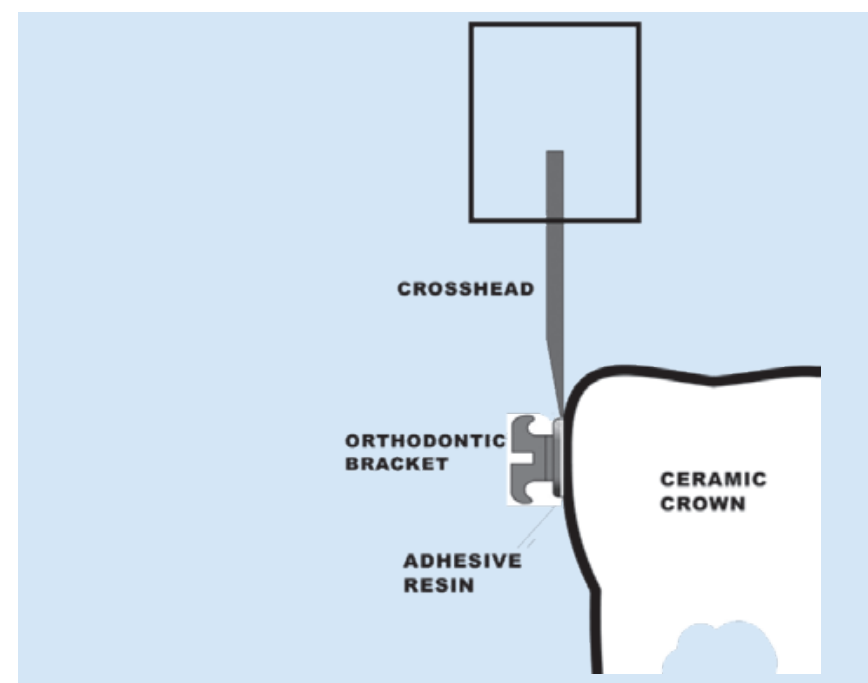

\section{SEM examination and ARI determination}

After debonding, the samples were analyzed using Scanning Electron Microscope (Tescan Vega TS5136MM, Chez Rep) and photomicrographs were taken, to determine Adhesive Remnant Index (ARI) and Porcelain Fracture Index (PFI). Before examination under SEM, the samples were dehydrated for $5 \mathrm{~h}$, in increasing concentrations of alcohol (70\% and 95\%). Subsequently, the non-conducting materials (ceramic brackets and both types of crowns) were coated with gold and palladium sputter (SC7620 Mini Sputter Coater, Quorum Technologies Ltd, UK). Furthermore, a localized chemical analysis was performed with Energy Dispersive X-ray Spectrometry (EDS) in representative samples, in order to determine the concentrations of the elements present in both types of ceramics.

In order to determine ARI (as per Bishara et al.) (25), the measurements were performed, using scores varying from 1 to 5: 1 - All adhesive remaining on the ceramic crown surface with the impression of the bracket base; 2 - More than $90 \%$ of the adhesive remaining on the ceramic crown surface; 3 - Less than $90 \%$, but more than $10 \%$ of the adhesive remaining on the surface; 4 - Less than $10 \%$ of the adhesive remaining on the ceramic crown surface; and 5 - No adhesive remaining on the ceramic crown surface.

Damage to the ceramic surface which may have occurred during shear bond testing was recorded using PFI (13). The index was divided into four scores as follows: 0 - ceramic surface intact or in the same condition as before the bonding procedure; 1 - surface damage limited to glaze layer or very superficial ceramic; 2 - surface damage which features significant loss of ceramic requiring restoration of the defect by composite resin or replacement of the restoration; 3 - surface damage where the core material has been exposed due to the depth of the cohesive failure.

\section{Statistical analysis}

The Kolmogorov-Smirnov test was used to test the distribution of SBS data. The hypothesis that SBS is similar in all the groups was tested using the univariate analysis of variance (ANOVA) with the ceramic type, bracket type and etching
Figure 1 Schematic illustration of SBS testing Slika 1. Shematski prikaz SBS testiranja

\section{Ispitivanje elektronskim mikroskopom (SEM) i određivanje indeksa zaostatnog sloja adheziva (ARI)}

Nakon odljepljivanja bravica uzorci su analizirani s pomoću elektronskog mikroskopa (Tescan Vega TS5136MM, Češka) te su napravljene fotomikrografije kako bi se odredili indeksi zaostatnog sloja adheziva (ARI) i loma keramike (PFI). Prije analize pod elektronskim mikroskopom uzorci su dehidrirani pet sati u povećanim koncentracijama alkohola (70 \% i $95 \%$ ). Posljedično, neprovodljivi materijali (keramičke bravice i obje vrste krunica) presvučeni su slojem zlata i paladija (SC7620 Mini Sputter Coater, Quorum Technologies Ltd, UK). Nadalje, lokalizirana kemijska analiza učinjena je spektrometrom Energy Dispersive X-ray (EDS) na reprezentativnom uzorku kako bi se odredila koncentracija elemenata u obje vrste keramike.

Kako bi se odredio indeks zaostatnog sloja adheziva (ARI) (prema Bishara i sur.) (25), obavljena su mjerenja, koristeći se rezultatima koji variraju od 1 do 5: 1 - sav adheziv ostao je na površini keramičke krunice s otiskom baze bravice; 2 - više od $90 \%$ adheziva ostalo je na površini keramičke krunice; 3 - manje od $90 \%$, ali više od $10 \%$ adheziva ostalo je na površini keramičke krunice; 4 - manje od $10 \%$ adheziva ostalo je na površini keramičke krunice; 5 - nema preostalog adheziva na površini keramičke krunice.

Oštećenje keramičke površine koje može nastati tijekom testiranja čvrstoće vezivanja zabilježeno je s pomoću indeksa loma keramike (PFI) (13). Indeks je podijeljen na četiri načina: 0 - keramička površina je intaktna, odnosno u istom stanju kao prije lijepljenja; 1 - oštećenje površine ograničeno je na sloj glazure, odnosno na površinsku keramiku; 2 - oštećenje površine koju karakterizira značajan gubitak keramike, što zahtijeva restauraciju defekta kompozitom ili zamjenu nadomjestka; 3 - oštećenje površine kada je vidljiva jezgra materijala zbog dubine kohezivnog neuspjeha.

\section{Statistička analiza}

Kolmogorov-Smirnovljev test korišten je za testiranje distribucije podataka o posmičnoj čvrstoći veze (SBS). Hipoteza da je SBS sličan u svim grupama testirana je s pomoću univarijantne analize varijance (ANOVA) sa svim vrstama kera- 
method as random factors. The significance level was set at 0.05 . The data were analyzed using STATISTICA 10 (StatSoft, Inc., version 10, www.statsoft.com).

\section{Results}

The results of SBS by ceramic type, bracket type, and etching method are shown in Table 1.

According to the results of the Kolmogorov-Smirnov test, SBS values are normally distributed (Kolmogorov-Smirnov $Z$ $=0.721, p=0.676)$. Test for equality of variances (Hartley F$\max =4.92$, Bartlett Chi-Sqr. $=7.33$, Cochran $\mathrm{C}=0.206, \mathrm{p}$ $=0.396)$ confirms that there is no significant difference between the variables of the individual subsamples i.e. the samples are homogeneous.

The results obtained from the univariate test of significance are presented in Table 2. They indicate that none of the factors or their interaction have a significant influence on the mean values of SBS. According to that, and explanations based on the Cohen criteria, variations of SBS are minor and in this case not significant.

The results are presented in Figure 2, where the mean SBS values and corresponding confidence interval (0.95) are mike, tipovima bravica i metodama jetkanja kao nasumičnim čimbenicima. Razina značajnosti postavljena je na 0,05 . Svi podatci analizirani su statističkim programom STATISTICA 10 (StatSoft, Inc., version 10, www.statsoft.com).

\section{Rezultati}

Rezultati posmične čvrstoće veze (SBS) prema vrsti keramike, vrsti bravica i metodama jetkanja prikazani su u tablici 1.

Prema rezultatima Kolmogorov-Smirnovljeva testa, SBS vrijednosti normalno su raspoređene (Kolmogorov-Smirnovljev $\mathrm{Z}=0,721, \mathrm{p}=0,676)$. Test za jednakost varijanci (Hartleyev F-maks. = 4,2, Bartlettov Chi-Sqr. = 7,33, Cochranov $\mathrm{C}=0,206, \mathrm{p}=0,396)$ potvrđuje da nema statistički značajne razlike između varijabli pojedinačnih podgrupa dakle, uzorak je homogen.

Rezultati dobiveni univarijantnim testom značajnosti nalaze se u tablici 2. Oni pokazuju da ni jedan čimbenik, ni njihove međusobne interakcije ne utječu značajno na srednje vrijednosti SBS-a. U skladu s tim i objašnjenjima vezanima uz Cochranove kriterije, varijacije SBS-a su minorne te u tom smislu beznačajne.

Rezultati su prikazani na slici 2., na kojoj srednje SBS vrijednosti odgovaraju intervalu pouzdanosti $(0,95)$ i prikazani

Table 1 Descriptive statistics of SBS by type of bracket (MPa)

Tablica 1. Deskriptivna statistika posmične čvrstoće veze (SBS) prema vrsti bravica (MP-a)

\begin{tabular}{|c|c|c|c|c|c|c|}
\hline $\begin{array}{l}\text { Type of Ceramic } \\
\text { Vrsta keramike }\end{array}$ & $\begin{array}{l}\text { Type of Bracket } \\
\text { Vrsta bravica }\end{array}$ & $\begin{array}{l}\text { Type of Etchant • } \\
\text { Način jetkanja }\end{array}$ & Group • Grupa & $\mathbf{N}$ & $\begin{array}{c}\text { Mean } \\
\text { Srednja vrijednost }\end{array}$ & SD \\
\hline \multirow{9}{*}{ 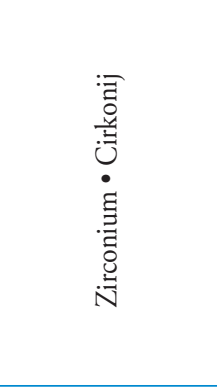 } & \multirow{3}{*}{ Metalic $\bullet$ Metalne } & $\mathrm{PhA}$ & 1 & 12 & 10.85 & 5.84 \\
\hline & & HFA & 2 & 12 & 11.84 & 7.30 \\
\hline & & Total & & 24 & 11.35 & 6.49 \\
\hline & \multirow{3}{*}{ Ceramic • Keramičke } & $\mathrm{PhA}$ & 3 & 12 & 8.52 & 4.72 \\
\hline & & HFA & 4 & 12 & 8.99 & 5.36 \\
\hline & & Total & & 24 & 8.75 & 4.94 \\
\hline & \multirow{3}{*}{ Total • Ukupno } & $\mathrm{PhA}$ & & 24 & 9.69 & 5.33 \\
\hline & & HFA & & 24 & 10.41 & 6.43 \\
\hline & & Total & & 48 & 10.05 & 5.85 \\
\hline \multirow{9}{*}{ 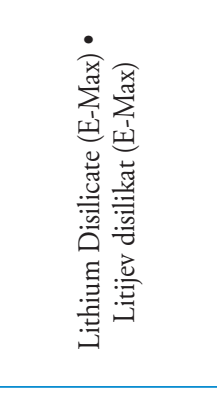 } & \multirow{3}{*}{ Metalic $\bullet$ Metalne } & $\mathrm{PhA}$ & 5 & 12 & 10.20 & 3.29 \\
\hline & & HFA & 6 & 12 & 11.95 & 5.96 \\
\hline & & Total & & 24 & 11.08 & 4.79 \\
\hline & \multirow{3}{*}{ Ceramic $・$ Keramičke } & $\mathrm{PhA}$ & 7 & 12 & 12.22 & 6.47 \\
\hline & & HFA & 8 & 12 & 10.31 & 5.67 \\
\hline & & Total & & 24 & 11.26 & 6.03 \\
\hline & \multirow{3}{*}{ Total • Ukupno } & $\mathrm{PhA}$ & & 24 & 11.21 & 5.13 \\
\hline & & HFA & & 24 & 11.13 & 5.75 \\
\hline & & Total & & 48 & 11.17 & 5.39 \\
\hline \multirow{9}{*}{ 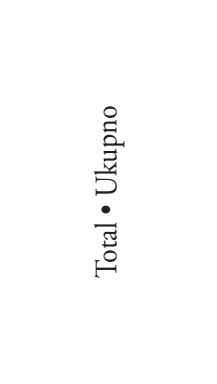 } & \multirow{3}{*}{ Metalic $・$ Metalne } & $\mathrm{PhA}$ & & 24 & 10.53 & 4.65 \\
\hline & & HFA & & 24 & 11.90 & 6.52 \\
\hline & & Total & & 48 & 11.21 & 5.64 \\
\hline & \multirow{3}{*}{ Ceramic $・$ Keramičke } & $\mathrm{PhA}$ & & 24 & 10.37 & 5.85 \\
\hline & & HFA & & 24 & 9.65 & 5.44 \\
\hline & & Total & & 48 & 10.01 & 5.60 \\
\hline & \multirow{3}{*}{ Total • Ukupno } & $\mathrm{PhA}$ & & 48 & 10.45 & 5.23 \\
\hline & & HFA & & 48 & 10.77 & 6.05 \\
\hline & & Total & & 96 & 10.61 & 5.62 \\
\hline
\end{tabular}


Table 2 Univariate test of significance for SBS (MPa)

Tablica 2. Univarijantni test značajnosti za SBS (MPa)

\begin{tabular}{|c|c|c|c|}
\hline Source $\bullet$ Izvor & $\mathbf{F}$ & p & Effect Size • Iznos \\
\hline Type of Ceramic (t-cer) • Vrsta keramike (ker.) & 0.934 & 0.336 & 0.011 \\
\hline Type of bracket (t-bra) ・ Vrsta bravica (bra.) & 1.072 & 0.303 & 0.012 \\
\hline Type of etchant (t-eth) • Način jetkanja (jet.) & 0.078 & 0.780 & 0.001 \\
\hline t-cer $\times$ t-bra $\bullet$ ker. $\times$ bra. & 1.431 & 0.235 & 0.016 \\
\hline t-cer $\times$ t-etc $\bullet$ ker. $\times$ jet. & 0.119 & 0.731 & 0.001 \\
\hline t-bra $\times$ t-etc $\bullet$ bra. $\times$ jet. & 0.808 & 0.371 & 0.009 \\
\hline t-cer $\times$ t-bra $\times$ t-etc $\bullet$ ker. $\times$ bra. $\times$ jet. & 0.454 & 0.502 & 0.005 \\
\hline
\end{tabular}

shown for the 8 groups generated from all three factors. Significant overlap is noticeable in these intervals.

According to the results of the chi-square test, the frequency of certain categories of ARI significantly depends only on the type of the bracket (chi-square $=14.85, \mathrm{df}=4, \mathrm{p}$ $=0.005)$. The first and the second category of ARI appear to have a significantly higher frequency regarding metallic brackets: first ARI category occurs only with metallic brackets, and the second in $87.5 \%$ of the cases also occurs with metallic brackets. The frequency of the third category of ARI is equally distributed in both types of brackets. Again, the fourth category of ARI is more frequent in ceramic brackets with $63.6 \%$. In the fifth category of ARI, the frequen-

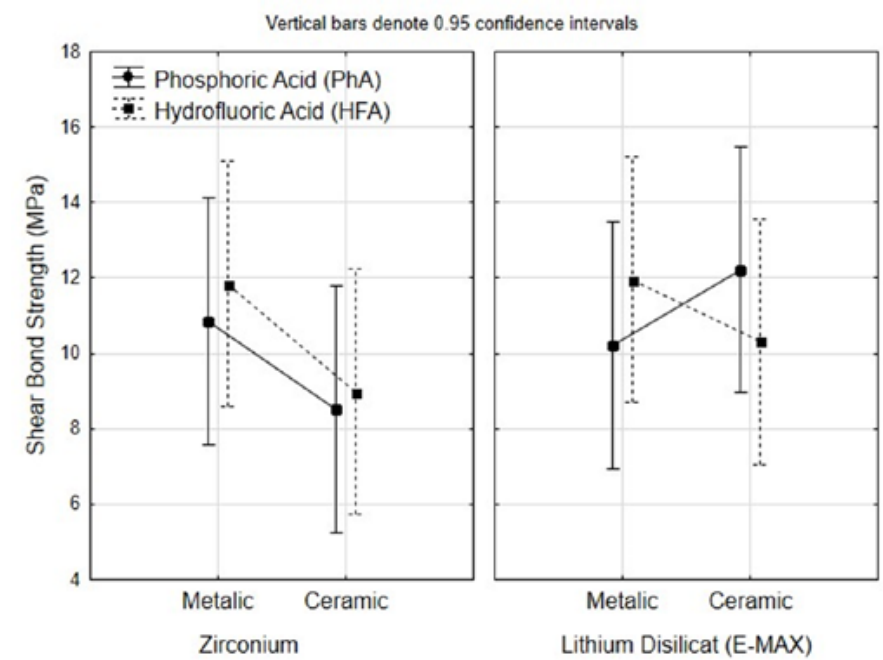

Figure 2 Means of shear bond strength (MPa) by type of ceramic, type of bracket and type of etchant su za svih osam skupina dobivenih od svih triju čimbenika. $U$ tim intervalima vidljivo je značajno preklapanje.

Prema rezultatima hi-kvadrat testa, frekvencija određenih kategorija indeksa zaostatnog sloja adheziva (ARI) značajno ovisi o vrsti bravica (hi-kvadrat $=14,85, \mathrm{df}=4, \mathrm{p}=0,005$ ). Prva i druga kategorija ARI-ja čini se značajnija u slučaju metalnih bravica: prva kategorija prisutna je jedino kod metalnih bravica, a druga u $87,5 \%$ slučajeva također je uočena kod metalnih bravica. Frekvencija treće kategorije ARI-ja jednako je raspoređena kod svih vrsta bravica. Na kraju, četvrta kategorija češća je kod keramičkih bravica i to $63,6 \%$. U petoj kategoriji zastupljenost ARI-ja gotovo je jednaka, $s$ blagom prednošću u korist keramičkih bravica $(53,8 \%)$. To je

\section{Slika 2. Srednje vrijednosti čvrstoće vezivanja (MP-a) prema vrsti keramike, vrsti bravica i načinu jetkanja} Lithium Disilicat (E-MAX)

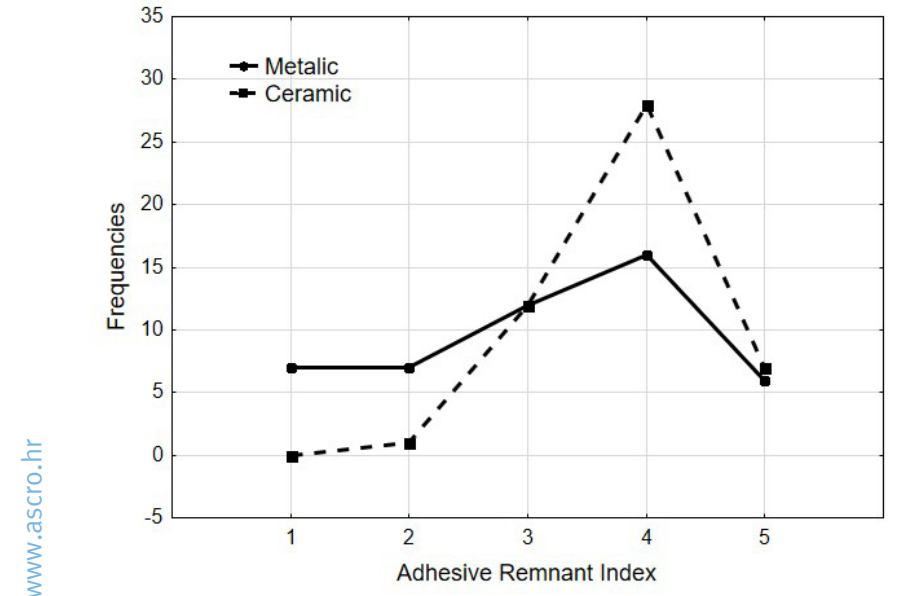

Figure 3 Frequencies of Adhesive Remnant Index by Type of Bracket

Slika 3. Frekvencije indeksa zaostatnog sloja adheziva (ARI) prema vrsti bravica 

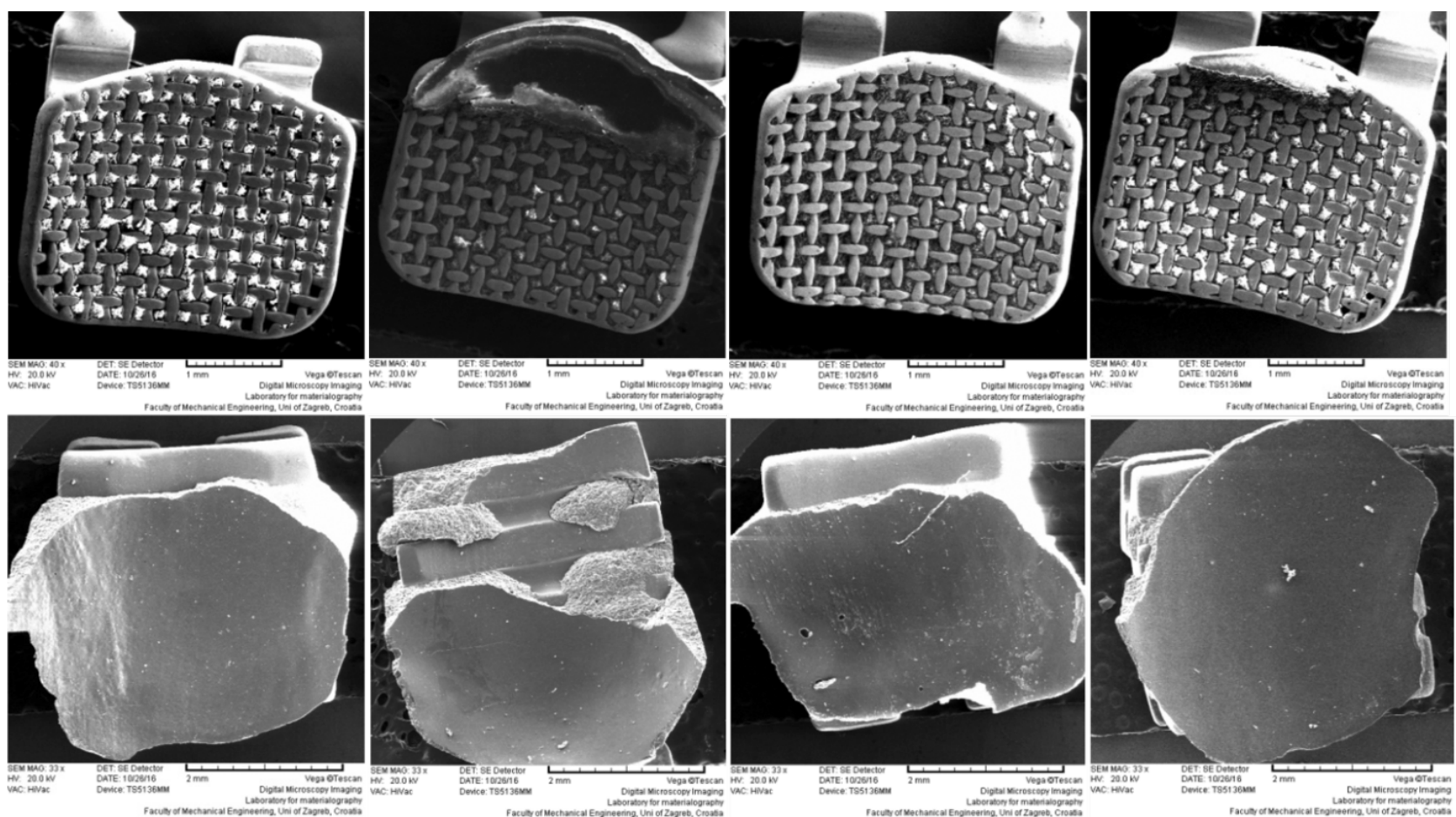

Figure 4 SEM photomicrographs of metallic (upper row) and ceramic (lower row) brackets to determine ARI.

Slika 4. SEM fotomikrograf metalnih (gornji red) i keramičkih (donji red) bravica za određivanje indeksa zaostatnog sloja adheziva (ARI-a)

cy is almost equal with a slight advantage of ceramic brackets $(53.8 \%)$. This is also illustrated in Figure 3 and also SEM photomicrographs are presented in Figure 4.

Porcelain fracture index (PFI) significantly differs from the type of etchant (chi-square $=4.746, \mathrm{df}=1, \mathrm{p}=0.029)$. The first PFI category (0) occurs significantly more frequently with the preparation of the substrate with $\mathrm{PhA}$, while the other category (1) is more frequently present with the preparation of substrates with HFA (Table 3). The two last categories were noticed in neither of the examined samples.

The SEM photomicrographs of the two ceramic surfaces etched with HFA revealed different surface morphologies. Zirconia ceramic displayed fewer pits and more unchanged glazed surfaces than the lithium disilicate ceramic. In both type of ceramic, the crowns etched with $\mathrm{PhA}$, loss of the glazed surface and mild roughening were observed. Uni- također prikazano na slici 3., a SEM fotomikrograf prikazan je na slici 4.

Indeks loma keramike (PFI) značajno se razlikuje od načina jetkanja (hi-kvadrat $=4,746, \mathrm{df}=1, \mathrm{p}=0,029)$. Prva PFI kategorija (0) zastupljena je znatno više kod uzorka s fosfornom kiselinom (PhA), a druga je (1) češća kod uzorka koji je pripremljen supstratom fluorovodične kiseline (HFA) (tablica 3.). Dvije zadnje kategorije nisu uočene ni kod jednog ispitivanog uzorka.

SEM fotomikrografija dviju keramičkih površina jetkanih fluorovodičnom kiselinom (HFA) otkrila je različitu površinsku morfologiju. Cirkonijeva keramika imala je manje jama i nepromijenjenih ostakljenih površina od litijeve disilikatne keramike. Kod oba tipa keramičkih krunica jetkanih fosfornom kiselinom $(\mathrm{PhA})$ uočen je gubitak ostakljene površine te blaga hrapavost. Također je zabilježeno ujednačeno

Table 3. Crosstabulation of PFI with a type of etchant $\chi^{2}$ - test

Tablica 3. Križno tabuliranje indeksa loma keramike (PFI), ovisno o načinu jetkanja $\chi^{2}-$ test

Porcelain fracture index $(\mathrm{PFI}) \bullet$ Indeks loma keramike (PFI)

Type of etchant $\bullet$ Način jetkanja

0 - ceramic surface intact or in the same condition as before the bonding procedure
0 - intaktna keramička površina ili u istim uvjetima kao i prije postupka lijepljenja
1 - surface damage limited to glaze layer or very superficial ceramic
1 - oštećenje površine ograničeno na glazuru ili vrlo površinski sloj keramike

Total $\bullet$ Ukupno

$\chi^{2}-$ test

${ }^{\text {a }}$ count, ${ }^{\mathrm{b}} \%$ within PFI $\bullet$ unutar PFI-ja

\begin{tabular}{c|c|c}
\multicolumn{2}{c}{ Type of etchant • Način jetkanja } & \\
$\begin{array}{c}\text { Phosphoric Acid } \\
(\mathbf{P h A}) \bullet \text { Fosforna } \\
\text { kiselina (PhA) }\end{array}$ & $\begin{array}{c}\text { Hydrofluoric } \\
\text { Acid (HFA) } \\
\text { Fluorovodična } \\
\text { kiselina (HFA) }\end{array}$ & $\begin{array}{c}\text { Total } \\
\text { Ukupno }\end{array}$ \\
\hline 21 & 10 & 31 \\
\hline $67.7 \%$ & $32.3 \%$ & $100.0 \%$ \\
\hline 27 & 38 & 65 \\
\hline $41.5 \%$ & $58.5 \%$ & $100.0 \%$ \\
\hline 48 & 48 & 96 \\
\hline $50.0 \%$ & $50.0 \%$ & $100.0 \%$ \\
\hline$\chi^{2}=4.746$ & $\mathrm{df}=1$ & $\mathbf{p = 0 . 0 2 9}$ \\
& & \\
\hline
\end{tabular}


form peeling or an erosive appearance with shallow penetration and undercuts was also observed (Figure 5).

Noticeable differences in chemical element concentrations of measurements with EDS between lithium disilicate (42\% O, 32\% Si, 9.3\% K, 8.6\% C, 3\% Al, 2.6\% W, 2.1\% $\mathrm{Zn})$ and zirconia $(48.6 \% \mathrm{Zr}, 43.2 \% \mathrm{O}, 5.7 \% \mathrm{Si}, 1 \% \mathrm{Al}, 0.9$ $\mathrm{K})$ are presented in Figure 6. ljuštenje i erozivan izgled s plitkim prodiranjem i potkopavanjem (slika 5.).

Značajne razlike u koncentraciji kemijskih elemenata $\mathrm{u}$ EDS mjerenjima između litijeva disilikata (42\% O, $32 \%$ $\mathrm{Si}, 9,3 \% \mathrm{~K}, 8,6 \% \mathrm{C}, 3 \% \mathrm{Al}, 2,6 \% \mathrm{~W}, 2,1 \% \mathrm{Zn})$ i cirkonija $(48,6 \% \mathrm{Zr}, 43,2 \% \mathrm{O}, 5,7 \% \mathrm{Si}, 1 \% \mathrm{Al}, 0,9 \mathrm{~K})$ prikazane su na slici 6 .
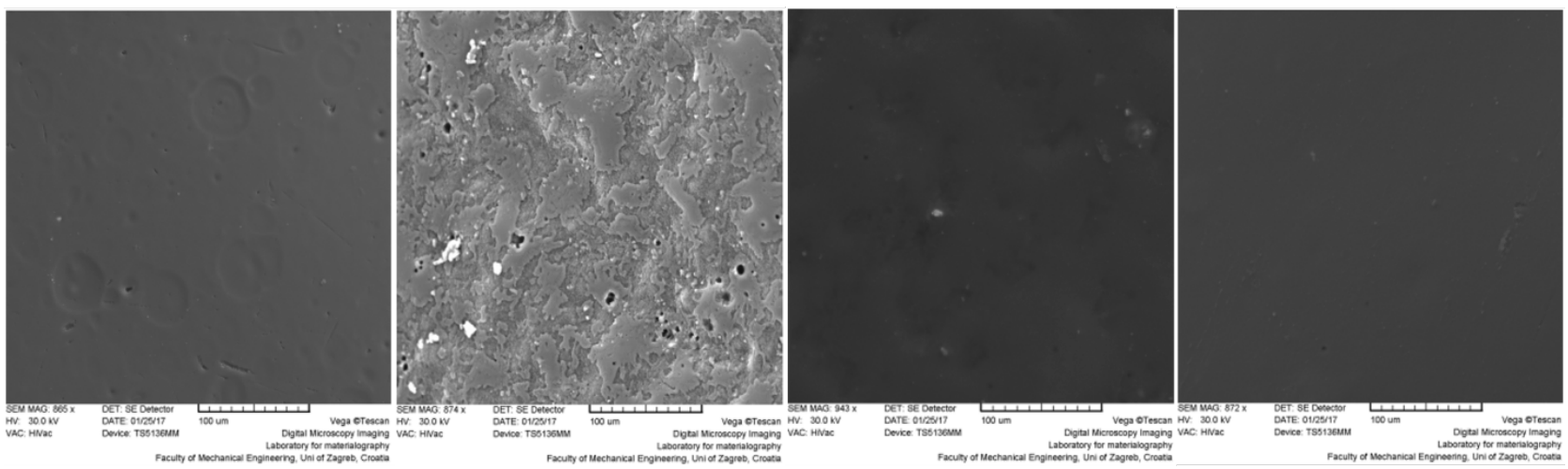

Figure 5 SEM images from ceramic surfaces (from left to right): a) Zirconia etched with HFA, b) Lithium disilicate etched with HFA, c) Zirconia etched with $\mathrm{PhA}$, and d) Lithium disilicate etched with $\mathrm{PhA}$.

Slika 5. SEM slika keramičke površine (slijeva nadesno): a) cirkonij jetkan fluorovodičnom kiselinom (HFA); b) litijev disilikat jetkan fluorovodičnom kiselinom (HFA); c) cirkonij jetkan fosfornom kiselinom (PhA); d) litijev disilikat jetkan fosfornom kiselinom (PhA)
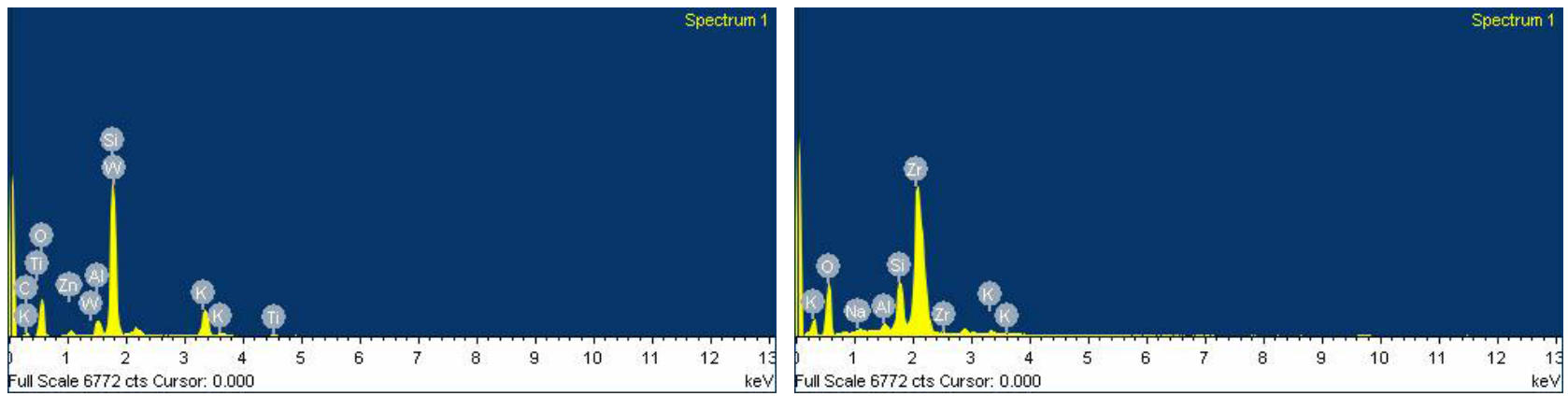

Figure 6 Graphical illustration of EDS measurements in lithium disilicate (a) and zirconia (b).

Slika 6. Grafički prikaz EDS mjerenja litijeva silikata (a) i cirkonija (b)

\section{Discussion}

When bonding brackets to ceramic surfaces, double challenges arise. In order to avoid bond failure, the optimal bond strength of 6 to $10 \mathrm{MPa}$ during the treatment is recommended (13). Again, after debonding, the restorations should remain in the same condition with their ideal esthetic and function $(4,26)$. Nevertheless, transferring this value in clinical work is questionable because of the complex environment of the oral cavity (14). In this research, the mean SBS values for all combinations were more than $6 \mathrm{MPa}$, but less than 13 $\mathrm{MPa}$, which may cause cracks in the ceramic (26).

The results of our PhA-etched groups show similar bond strengths to those etched with HFA, which is consistent with the results of other studies $(6,13,22)$.

According to numerous studies $(4,6,13,24,25)$, the bond strength of ceramic brackets is higher than the strength of metallic brackets. But, our results indicate that this doesn't occur at orthodontic brackets bonded to zirconia restorations,

\section{Rasprava}

Pri lijepljenju bravica na keramičke površine mnogo je izazova. Kako bi se izbjegle pogreške, optimalna čvrstoća vezivanja bravica za keramičke krunice tijekom ortodontske terapije trebala bi iznositi 6 do $10 \mathrm{MP}-\mathrm{a}$ (13). Nakon skidanja bravica restauracije bi trebale ostati nepromijenjene kad je riječ o estetici i funkciji kao i prije terapije. $(4,26)$. Štoviše, implementacija toga u klinički rad upitna je zbog drukčijih uvjeta u usnoj šupljini (14). U ovom istraživanju srednje vrijednosti posmične čvrstoće vezivanja (SBS) u svim su kombinacijama bile veće od $6 \mathrm{MP}$-a i manje od $13 \mathrm{MP}$-a, što može rezultirati pucanjem keramike (26).

Rezultati za skupinu koja je jetkana fosfornom kiselinom pokazuju sličnu posmičnu čvrstoću vezivanja kao i u skupini jetkanoj fluorovodičnom kiselinom, što se slaže s rezultatima drugih istraživanja $(6,13,22)$.

Prema mnogobrojnim istraživanjima $(4,6,13,24,25)$, čvrstoća vezivanja keramičkih bravica veća je od čvrstoće ve- 
and this is in accordance with a study previously reported by Mehmeti et al. (2017) (27), where metallic brackets, in comparison with ceramic brackets, bond better with zirconia restorations. This might be because of the base surface design of metallic brackets, producing a better mechanical coupling with zirconia ceramic substrate. Furthermore, this was not the case in most of our groups with ceramic brackets, except group 7 showing the best result, however still not significant in comparison with metallic bracket groups. In general, ceramic brackets bonded to lithium disilicate samples, compared to those bonded to zirconia, showed slightly but not significantly higher SBS values. The highest difference between the lithium disilicate and zirconia was registered in a ceramic bracket and phosphoric acid groups, probably due to the variations in the chemical compositions of these two ceramic materials.

Regardless of the type of ceramic and its surface conditioning, the samples with metallic brackets have shown mixed adhesive-cohesive failures. In the majority of the samples with ceramic brackets, adhesive failures were noticed (scale 4 or 5), which indicates that the bond strength between the composite and the ceramic bracket was stronger than the bond strength between the composite and ceramic crown. This type of failure is desired to avoid ceramic breakage during debonding (28). Our findings are partially in concordance with the above mentioned findings.

Furthermore, in neither of the all-ceramic types larger fractures or cracks were observed, which is clinically important for the long-term integrity of the restoration. The significant difference between two etchants regarding PFI that was noticed is in agreement with other studies $(6,13)$ and may indicate that the use of HFA can make more vulnerable the ceramic surface of both all-ceramic materials.

Our findings may indicate that the use of HFA is unnecessary for conditioning the ceramic surface before bonding orthodontic brackets. However, this research was conducted under in vitro conditions, which are not always possible to compare with clinical situations. According to Bourk and Rock (1999), thermocycling weakens bond strength and is recommended in order to simulate the conditions in the oral cavity (13). On the other hand, Smith et al. (1988) stated that thermocycling had no significant effect on SBS (28). However, in this research, thermocycling was performed as a mean of artificial aging of the bond prior to testing.

Despite limitations, SBS testing remains a relevant methodology to compare bonding protocols by providing important information regarding bracket debonding in clinical situations (29).

\section{Conclusion}

The results of this paper lead us to the conclusion that the use of HFA for surface etching of zirconia and/or lithium disilicate does not cause a significant rise of the $S B S$ values in comparison to etch with PhA and silane application. Furthermore, HFA can weaken the surface structure of the ceramic, and considering its adverse effect, might not be the best suitable conditioner prior to orthodontic bonding to lithium di- zivanja metalnih bravica. No u našem istraživanju to se nije pokazalo točnim kada su se keramičke bravice lijepile na cirkonijeve krunice, što se slaže s ranijim istraživanjima Mehmetija i suradnika (2017.) (27) koji su istaknuli da se metalne bravice, u usporedbi s keramičkima, bolje lijepe na krunice od cirkonija. Razlog za to može biti oblik baze metalnih bravica koji stvara bolju mehaničku vezu s cirkonijevom keramikom. Nadalje, u našem istraživanju to nije bio slučaj u većini skupina s keramičkim bravicama, osim u sedmoj skupini u kojoj su postignuti najbolji rezultati, ali još nedovoljno značajni u usporedbi sa skupinom s metalnim bravicama. Općenito, keramičke bravice lijepljene na litijeve disilikatne uzorke, u usporedbi s onima lijepljenima na cirkonij, pokazale su neznatne, a ne značajno veće vrijednosti posmične čvrstoće veze (SBS). Najveća razlika između litijeva disilikata i cirkonija zabilježena je za keramičke bravice kojima su površine jetkane fosfornom kiselinom, vjerojatno zbog različitosti u kemijskom sastavu tih dvaju keramičkih materijala. Bez obzira na vrstu keramike i način jetkanja, uzorci s metalnim bravicama pokazali su različitosti kod adhezivno-kohezivnih pogrešaka. Na većini uzoraka $s$ keramičkim bravicama uočene su pogreške pri vezivanju (ljestvica 4 ili 5), što pokazuje da je čvrstoća veze između kompozita i keramičke bravice jača od one između kompozita i keramičke krunice. Takva vrsta veze poželjna je kako bi se izbjeglo pucanje keramike pri skidanju bravica (28). Rezultati našeg istraživanja djelomično se slažu $s$ navedenim. Nadalje, ni kod jedne vrste potpune keramike nisu pronađeni veći lomovi ili pukotine, što je klinički važno za dugoročni integritet keramičke restauracije. Značajnija razlika koja je primijećena između načina jetkanja u odnosu prema indeksu loma keramike slaže se s ostalim istraživanjima $(6,13)$ te može upućivati na to da uporaba fluorovodične kiseline može keramičku površinu obiju vrsta potpune keramike učiniti mnogo osjetljivijom.

Rezultati našeg istraživanja pokazuju da uporaba fluorovodične kiseline nije nužna za jetkanje keramičke površine prije lijepljenja bravica. No ovo istraživanje provedeno je in vitro, što se ne može uvijek usporediti s kliničkim uvjetima. Prema Bourku i Rocku (1999.), termocikliranje oslabljuje čvrstoću vezivanja, a ipak se preporučuje kako bi se simulirali uvjeti u usnoj šupljini. (13). S druge strane, Smith i suradnici (1988.) ističu da termocikliranje nema veći utjecaj na posmičnu čvrstoću veze (SBS) (28). No u ovom istraživanju termocikliranje je provedeno kao sredstvo za umjetno oslabljivanje veze prije ispitivanja. Unatoč ograničenjima, ispitivanje posmične čvrstoće vezivanja (SBS) ostaje relevantna metodologija kojom se uspoređuju protokoli lijepljenja kako bi se dobile važne informacije o skidanju bravica u kliničkim uvjetima (29).

\section{Zaključak}

Dobiveni rezultati istraživanja navode na zaključak da jetkanje fluorovodičnom kiselinom u svrhu hrapavljenja površine cirkonijeve i litijeve disilikatne keramike ne utječe na bolju posmičnu čvrstoću veze u usporedbi $s$ jetkanjem fosfornom kiselinom uz primjenu silana. Nadalje, fluorovodična kiselina može oslabiti površinsku strukturu keramike te, uzimajući u obzir njezin štetan učinak na oralnu sluznicu, nije najbolji iz- 
silicate, and in particular to zirconia, also taking into account its crystalline structure.

Regarding the orthodontic point of view, zirconia and lithium disilicate all-ceramic restorations, as well as both types of brackets and both type of etchants, have similar features and provide strong enough values to ensure appropriate treatment.

\section{Conflict of interest}

The authors report no conflict of interest. bor za jetkanje prije lijepljenja bravica na litijevu disilikatnu keramiku, ali ni na cirkonij, također uzimajući u obzir njezinu kristaličnu strukturu.

S ortodontskog stajališta, cirkonijeve i litijeve disilikatne potpuno keramičke krunice te bravice od obje vrste materijala, korištenjem obaju načina jetkanja, pokazuju slična svojstva i osiguravaju dovoljno čvrstu vezu za uspješnost ortodontske terapije.

\section{Sukob interesa}

Autori nisu bili u sukobu interesa.
Sažetak

Cilj: Analizirani su posmična čvrstoća veze (SBS) i indeks zaostatnog sloja adheziva (ARI) keramičkih i metalnih ortodontskih bravica nalijepljenih na cirkonijeve i litijeve disilikatne krunice koje se koriste za protetičke restauracije najetkane fluorovodičnom (HFA) ili fosfornom kiselinom (PhA) te se određivao indeks loma keramike (PFI) kako bi se proučila keramička površina nakon skidanja bravica. Materijali i metode: Istraživanje je provedeno na 96 potpuno keramičkih uzoraka zuba podijeljenih u osam skupina prema vrsti keramike, različitosti materijala od kojih su napravljene ortodontske bravice te jetkanju površine. Posmična čvrstoća veze (SBS) testirana je s pomoću univerzalnog uređaja za testiranje, a uzorci su analizirani elektronskim mikroskopom kako bi se odredio indeks zaostatnog sloja adheziva (ARI) i indeks loma keramike (PFI). Statistički podatci dobiveni su s pomoću testa ANOVA-e s razinom značajnosti $\alpha=0,05$. Rezultati: Litijev disilikat pokazao je bolju mogućnost vezivanja u gotovo svim skupinama. No nije pronađena značajnija razlika između skupina i ni jedan od čimbenika nije znatnije utjecao na srednje vrijednosti SBS-a $(p>0,05)$. Naime, ARI je značajno ovisio o vrsti bravica $(p=0,005)$, a PFI o vrsti jetkača $(p=0,029)$. Zaključak: Uporaba fluorovodične kiseline (HFA) za hrapavljenje cirkonijeve i litijeve disilikatne površine ne utječe na povećanje čvrstoće vezivanja u usporedbi s hrapavljenjem površine fosfornom kiselinom i silanom. Nadalje, fluorovodična kiselina može oslabiti površinsku strukturu keramike, a uzimajući u obzir njezinu toksičnost, nije najprikladnija za nanošenje prije lijepljenja ortodontskih bravica na litijeve disilikatne i cirkonijeve površine, također uzimajući u obzir njihovu kristaličnu strukturu.
Zaprimljen: 15. studenoga 2018.

Prihvaćen: 1. veljače 2019.

Adresa za dopisivanje

Sandra Anić-Milošević

Sveučilište u Zagrebu

Stomatološki fakultet

Gundulićeva 5, 10000 Zagreb,

Hrvatska

tel: +38514802173

sanic@sfzg.hr

\section{Ključne riječi}

ortodontske bravice; posmična čvrstoća veze; krunice; indeks zaostatnog sloja adheziva (ARI); indeks loma keramike (PFI); cirkonij; smjese litija

\section{References}

1. Zarone F, Russo S, Sorrentino R. From porcelain-fused-to-metal to zirconia: Clinical and experimental considerations. Dent Mater. 2011 Jan;27(1):83-96.

2. MeSH Browser [database on the Internet]. Lee JY, Kim JS, Hwang CJ. Comparison of shear bond strength of orthodontic brackets using various zirconia primers. Korean J Orthod. 2015;45(4):16470. Available from: http://www.ncbi.nlm.nih.gov/pubmed/26258062

3. Bilgic F, Alkis H, Gungor AY, Tuncdemir AR, Malkoc MA. Shear Bond Strength of Ceramic Brackets Bonded to Three Different Porcelain Surfaces. Eur J Prosthodont. 2013;1(1):17-20.

4. Al-Hity R, Gustin MP, Bridel N, Morgon L, Grosgogeat B. In vitro orthodontic bracket bonding to porcelain. Eur J Orthod. 2012 Aug;34(4):505-11.

5. Jurisic S, Jurisic G, Juric H. Influence of Adhesives and Methods of Enamel Pretreatment on the Shear Bond Strength of Orthodontic Brackets. Acta Stomatol Croat. 2015 Dec;49(4):269-74.

6. Alhaija ESJA, Alreesh IAA, Alwahadni AMS. Factors affecting the shear bond strength of metal and ceramic brackets bonded to different ceramic surfaces. Eur J Orthod. 2010 Jun;32(3):274-80.

7. Denry I, Holloway JA. Ceramics for dental applications: A review. Materials. 2010;3(1):351-68.

8. Mobilio N, Fasiol A, Mollica F, Catapano S. Effect of different luting agents on the retention of lithium disilicate ceramic crowns. Materials. 2015;8(4):1604-11.

9. Jurisic S, Jurisic G, Knezovic-Zlataric D. In Vitro Evaluation and Comparison of the Translucency of Two Different All-Ceramic Systems. Acta Stomatol Croat. 2015 Sep;49(3):195-203.

10. Whitlock BO, Eick JD, Ackerman RJ, Glaros AG, Chappell RP. Shear strength of ceramic brackets bonded to porcelain. Am J Orthod Dentofacial Orthop. 1994 Oct;106(4):358-64.

11. Zachrisson Y, Zachrisson BU. Surface preparation for orthodontic bonding to porcelain. Am J Orthod Dentofacial Orthop. 1996 Apr;109(4):420-30.

12. Ajlouni R, Bishara SE, Oonsombat C, Soliman M, Laffoon J. The effect of porcelain surface conditioning on bonding orthodontic brackets. Angle Orthod. 2005 Sep;75(5):858-64.
13. MeSH Browser [database on the Internet]. Bourke BM, Rock WP. Factors affecting the shear bond strength of orthodontic brackets to porcelain. Br J Orthod. 1999;26(4):285-90. Available from: http://www.ncbi.nlm.nih.gov/pubmed/10592155

14. Zachrisson BU. Orthodontic bonding to artificial tooth surfaces Clinical versus laboratory findings. Am J Orthod Dentofacial Orthop. 2000 May;117(5):592-4.

15. Barbosa VLT, Almeida MA, Chevitarese O, Olga Keith. Direct bonding to porcelain. Am J Orthod Dentofacial Orthop. 1995 Feb;107(2):159-64.

16. Peterson IM, Wuttiphan S, Lawn BR, Chyung K. Role of microstructure on contact damage and strength degradation of micaceous glass-ceramics. Dent Mater. 1998 Jan;14(1):80-9.

17. Martins ARM, Gotti VB, Shimano MM, Borges GA, Gonçalves LDS. Improving adhesion between luting cement and zirconia-based ceramic with an alternative surface treatment. Braz Oral Res. 2015;29:54.

18. PA Moore, Manor R. Hydrofluoric acid burns. J Prosthet Dent. 1982;(47):338-9.

19. Poosti M, Jahanbin A, Mahdavi P, Mehrnoush S. Porcelain conditioning with Nd: YAG and Er: YAG laser for bracket bonding in orthodontics. Lasers Med Sci. 2012 Mar;27(2):321-4.

20. Topcuoglu T, Oksayan R, Topcuoglu S, Coskun ME, Isman NE. Effect of Er: YAG laser pulse duration on shear bond strength of metal brackets bonded to a porcelain surface. Photomed Laser Surg. 2013 Jun;31(6):240-6.

21. Pich O, Franzen R, Gutknecht N, Wolfart S. Laser treatment of dental ceramic/cement layers: transmitted energy, temperature effects, and surface characterization. Lasers Med Sci. 2015;30(2):591-7.

22. Faltermeier A, Reicheneder C, Götzfried P, Prof P. Bonding Orth odontic Ceramic Brackets to Ceramic Restorations: Evaluation of Different Surface Conditioning Methods. Mat Sci Appl. 2013;2013(7):10-4.

23. Mehmeti B, Haliti F, Azizi B, Kelmendi J, Iljazi-Shahiqi D, Jakovljevic S, Anic-Milosevic S. Influence of different orthodontic brack- 
ets and chemical preparations of ceramic crowns on shear bond strength. AMJ. 2018;11(2):107-112.

24. Kocadereli I, Canay S, Akca K. Tensile bond strength of ceramic orthodontic brackets bonded to porcelain surfaces. Am J Orthod Dentofacial Orthop. 2001 Jun;119(6):617-20.

25. Bishara SE, Olsen ME, VonWald L, Jakobsen JR. Comparison of the debonding characteristics of two innovative ceramic bracket designs. Am J Orthod Dentofacial Orthop. 1999 Jul;116(1):86-92.

26. Thurmond JW, Barkmeier WW, Wilwerding TM. Effect of porcelain surface treatments on bond strengths of composite resin bonded to porcelain. J Prosthet Dent. 1994 Oct;72(4):355-9.
27. Mehmeti B, Azizi B, Kelmendi J, Iljazi-Shahiqi D, Alar Z, Anic-Milosevic S. Shear Bond Strength of Orthodontic Brackets Bonded to Zirconium Crowns. Acta Stomatol Croat. 2017;51(2):99-105.

28. Smith GA, McInnes-Ledoux P, Ledoux WR, Weinberg R. Orthodontic bonding to porcelain-Bond strength and refinishing. Am J Orthod Dentofacial Orthop. 1988 Sep;94(3):245-52.

29. Katona TR, Long RW. Effect of loading mode on bond strength of orthodontic brackets bonded with 2 systems. Am J Orthod Dentofacial Orthop 2006;129(1):60-4. Available from: http://www.ncbi. nlm.nih.gov/pubmed/16443480 